\title{
Front Matter: Volume 7825
}

, "Front Matter: Volume 7825," Proc. SPIE 7825, Remote Sensing of the Ocean, Sea Ice, and Large Water Regions 2010, 782501 (29 October 2010); doi: $10.1117 / 12.881733$

SPIE. Event: SPIE Remote Sensing, 2010, Toulouse, France 


\section{PROCEEDINGS OF SPIE}

\section{Remote Sensing of the Ocean, Sea lce, and Large Water Regions 2010}

Charles R. Bostater, Jr.

Stelios P. Mertikas

Xavier Neyt

Miguel Velez-Reyes

Editors

21-23 September 2010

Toulouse, France

Sponsored by

SPIE

Cooperating Organizations

European Association of Remote Sensing Companies (Belgium)

EOS-European Optical Society

CNES-Centre National d'Etudes Spatiales (France)

Deutsche Gesellschaft für Photogrammetrie, Fernerkundung, und Geoinformation e.V.

(Germany)

Remote Sensing and Photogrammetry Society (United Kingdom)

SFPT-Société Française de Photogrammétrie et de Télédétection (France)

Published by

SPIE

Volume 7825 
The papers included in this volume were part of the technical conference cited on the cover and title page. Papers were selected and subject to review by the editors and conference program committee. Some conference presentations may not be available for publication. The papers published in these proceedings reflect the work and thoughts of the authors and are published herein as submitted. The publisher is not responsible for the validity of the information or for any outcomes resulting from reliance thereon.

Please use the following format to cite material from this book:

Author(s), "Title of Paper," in Remote Sensing of the Ocean, Sea Ice, and Large Water Regions 2010, edited by Charles R. Bostater, Jr., Stelios P. Mertikas, Xavier Neyt, Miguel Velez-Reyes, Proceedings of SPIE Vol. 7825 (SPIE, Bellingham, WA, 2010) Article CID Number.

ISSN 0277-786X

ISBN 9780819483423

Published by

SPIE

P.O. Box 10, Bellingham, Washington 98227-0010 USA

Telephone +1 3606763290 (Pacific Time) · Fax +1 3606471445

SPIE.org

Copyright (C) 2010, Society of Photo-Optical Instrumentation Engineers

Copying of material in this book for internal or personal use, or for the internal or personal use of specific clients, beyond the fair use provisions granted by the U.S. Copyright Law is authorized by SPIE subject to payment of copying fees. The Transactional Reporting Service base fee for this volume is $\$ 18.00$ per article (or portion thereof), which should be paid directly to the Copyright Clearance Center (CCC), 222 Rosewood Drive, Danvers, MA 01923. Payment may also be made electronically through CCC Online at copyright.com. Other copying for republication, resale, advertising or promotion, or any form of systematic or multiple reproduction of any material in this book is prohibited except with permission in writing from the publisher. The CCC fee code is 0277-786X/10/\$18.00.

Printed in the United States of America.

Publication of record for individual papers is online in the SPIE Digital Library.

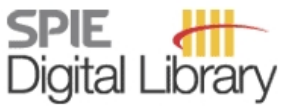

SPIEDigitalLibrary.org

Paper Numbering: Proceedings of SPIE follow an e-First publication model, with papers published first online and then in print and on CD-ROM. Papers are published as they are submitted and meet publication criteria. A unique, consistent, permanent citation identifier (CID) number is assigned to each article at the time of the first publication. Utilization of CIDs allows articles to be fully citable as soon they are published online, and connects the same identifier to all online, print, and electronic versions of the publication. SPIE uses a six-digit CID article numbering system in which:

- The first four digits correspond to the SPIE volume number.

- The last two digits indicate publication order within the volume using a Base 36 numbering system employing both numerals and letters. These two-number sets start with 00, 01, 02, 03, 04, $05,06,07,08,09,0 A, 0 B \ldots 0 Z$, followed by 10-1Z, 20-2Z, etc.

The CID number appears on each page of the manuscript. The complete citation is used on the first page, and an abbreviated version on subsequent pages. Numbers in the index correspond to the last two digits of the six-digit CID number. 


\section{Contents}

vii Conference Committee
ix Introduction

PAPER FROM JOINT SESSION WITH CONFERENCE 7826: SENSORS, SYSTEMS, AND

NEXT-GENERATION SATELLITES XIV

Xi EUFAR, the European facility for airborne research, becomes 10 [7826 IW]

I. Reusen, VITO NV (Belgium); J.-L. Brenguier, Meteo-France CNRM, GMEl (France)

SESSION 1 WATER COLUMN PROPERTIES AND SST IMAGING AND ALGORITHMS

782502 Effects of a frontal passage on surface salinity distribution along the Louisiana-Texas coast, USA, from ocean color and model outputs (Invited Paper) [7825-01]

E. J. D'Sa, Louisiana State Univ. (United States); D. S. Ko, U.S. Naval Research Lab. (United States)

782503 Empirical Orthogonal Function (EOF) analysis of sea-surface temperature and chlorophyll in the eastern Bering Sea [7825-02]

P. Naik, E. J. D'Sa, Louisiana State Univ. (United States)

782504 Validation of ocean color satellite sensors using coastal observational platform in Long Island Sound [7825-03]

S. Hlaing, T. Harmel, A. Ibrahim, I. Ioannou, A. Tonizzo, A. Gilerson, S. Ahmed, The City College of New York (United States)

782506 Detection of surface algal blooms using the newly developed algorithm surface algal bloom index (SABI) [7825-06]

F. Alawadi, Univ. of Southampton (United Kingdom)

SESSION 2 SAR, MICROWAVE, AND ALTIMETRY: RS OF WATER I

782507 SRAL, a radar altimeter designed to measure several surface types [7825-07]

Y. Le Roy, M. Deschaux-Beaume, Thales Alenia Space (France); C. Mavrocordatos, F. Borde,

European Space Agency (Netherlands)

782508 Microwave satellite data to quantify effects of global climate change on arctic rivers [7825-08]

Z. Kugler, Budapest Univ. of Technology and Economics (Hungary); R. Brakenridge,

Dartmouth College (United States); T. De Groeve, DG-Joint Research Ctr. (Italy) 
782509 Oil spill classification from multi-spectral satellite images: exploring different machine learning techniques (Invited Paper) [7825-09]

L. Corucci, Univ. di Pisa (Italy); F. Nardelli, Flyby S.r.l. (Italy); M. Cococcioni, Univ. di Pisa (Italy)

7825 OA Optimization of RADARSAT-2 SAR imagery for vessel detection applications [7825-10]

K. Beckett, A. Thompson, A. Luscombe, G. Stirling, MDA Systems Ltd. (Canada)

7825 OC Absolute calibration of Jason satellite radar altimeters at Gavdos Cal/Val facility using independent techniques [7825-12]

S. P. Mertikas, A. Daskalakis, V. Tserolas, Technical Univ. of Crete (Greece); W. Hausleitner, Space Research Institute (Austria); I. N. Tziavos, G. S. Vergos, Aristotle Univ. of Thessaloniki (Greece); V. Zervakis, Univ. of the Aegean (Greece); X. Frantzis, A. Tripolitsiotis,

P. Partsinevelos, D. Andrikopoulos, Technical Univ. of Crete (Greece)

7825 OD Simulation and evaluation for measuring directional ocean wave spectrum from SWIM on CFOSAT [7825-13]

L. Ren, Nanjing Univ. of Science and Technology (China) and The Second Institute of Oceanography, SOA (China); D. Pan, Z. Mao, D. Wang, J. Chen, The Second Institute of Oceanography, SOA (China)

\section{SESSION 4 WATER SURFACE AND SUBSURFACE SENSING}

$7825 \mathrm{OE} \quad$ Experimentally based simulations on modulated lidar for shallow underwater target detection and localization (Invited Paper) [7825-14]

$\checkmark$. Jezequel, Univ. Européene de Bretagne (France) and Univ. de Bretagne Occidentale (France); F. Audo, Ecole Nationale d'Ingénieurs de Brest (France); F. Pellen, B. Le Jeune, Univ. Européene de Bretagne (France) and Univ. de Bretagne Occidentale (France)

7825 OF Sensitivity of the above water polarized reflectance to the water composition [7825-15] A. Tonizzo, T. Harmel, A. Ibrahim, S. Hlaing, I. Ioannou, A. Gilerson, CUNY (United States); J. Chowdhary, Columbia Univ. (United States); B. Gross, F. Moshary, S. Ahmed, CUNY (United States)

7825 OG Investigation of surface roughness with optical methods [7825-16] V. I. Titov, E. M. Zuikova, A. G. Luchinin, J. I. Troitzkaya, Institute of Applied Physics (Russian Federation)

$7825 \mathrm{OH}$ Image analysis for water surface and subsurface feature detection in shallow waters [7825-17]

C. R. Bostater, Jr., J. Jones, H. Frystacky, M. Kovacs, O. Jozsa, Florida Institute of Technology (United States)

$7825 \mathrm{Ol}$ Airborne validation of a new-style ultraviolet push-broom camera for ocean oil spills pollution surveillance [7825-29]

D. Yin, X. Huang, W. Qian, X. Huang, Y. Li, Q. Feng, Shanghai Institute of Technical Physics (China) 
SESSION 5 AIRBORNE REMOTE SENSING: PROGRAMS AND DATA SETS: JOINT SESSION WITH CONFERENCE 7826

7825 OK Airborne surveillance of water basins with hyperspectral FLS ${ }^{-}$Lidar (Invited Paper) [7825-20] S. Babichenko, V. Alekseyev, J. Lapimaa, A. Lisin, L. Poryvkina, S. Shchemelyov, I. Sobolev, L. Vint, Laser Diagnostic Instruments AS (Estonia)

$7825 \mathrm{OM}$ An oil film information retrieval method overcoming the influence of sun glitter, based on AISA+ airborne hyper-spectral image [7825-22]

Y. Zhan, T. Mao, F. Gong, D. Wang, J. Chen, The Second Institute of Oceanography, SOA (China)

$7825 \mathrm{ON}$ Integration, testing, and calibration of imaging systems for land and water remote sensing [7825-23]

C. R. Bostater, J. Jones, H. Frystacky, M. Kovacs, O. Jozsa, Florida Institute of Technology (United States)

\section{POSTER SESSION}

782500 Study on Bayesian hierarchal model-based SST data fusion methods [7825-24]

P. Guo, Henan Institute of Meteorological Sciences (China)

7825 OR Influence of wind roughness on the time characteristics of impulse airborne ocean lidars [7825-27]

A. G. Luchinin, Institute of Applied Physics (Russian Federation)

7825 OS Effects of suspended matter concentration on algae spectrum's characteristic positions in Hangzhou Bay, China [7825-28]

Q. Cheng, X. WU, Zhejiang Gongshang Univ. (China)

Author Index 
Downloaded From: https://www.spiedigitallibrary.org/conference-proceedings-of-spie on 26 Apr 2023

Terms of Use: https://www.spiedigitallibrary.org/terms-of-use 


\title{
Conference Committee
}

\author{
Symposium Chair \\ Steven P. Neeck, NASA Headquarters (United States) \\ Symposium Cochair \\ Karin Stein, Fraunhofer-Institut für Optronik, Systemtechnik und \\ Bildauswertung (Germany) \\ Conference Chairs
}

Charles R. Bostater, Jr., Florida Institute of Technology (United States)

Stelios P. Mertikas, Technical University of Crete (Greece)

Xavier Neyt, Royal Belgian Military Academy (Belgium)

Miguel Velez-Reyes, University de Puerto Rico Mayagüez (United States)

Program Committee

Karine Caillault, ONERA (France)

Eurico J. D'Sa, Louisiana State University (United States)

Alex Gilerson, The City College of New York (United States)

Ana M. Martins, Universidade dos Açores (Portugal)

Session Chairs

1 Water Column Properties and SST Imaging and Algorithms

Eurico D'Sa, Louisiana State University (United States)

2 SAR, Microwave, and Altimetry: RS of Water I

Stelios P. Mertikas, Technical University of Crete (Greece)

3 SAR, Microwave, and Altimetry: RS of Water II

Stelios P. Mertikas, Technical University of Crete (Greece)

$4 \quad$ Water Surface and Subsurface Sensing

Xavier Neyt, Royal Belgian Military Academy (Belgium)

$5 \quad$ Airborne Remote Sensing: Programs and Data Sets: Joint Session with Conference 7826

Charles R. Bostater, Jr., Florida Institute of Technology (United States) 
Downloaded From: https://www.spiedigitallibrary.org/conference-proceedings-of-spie on 26 Apr 2023

Terms of Use: https://www.spiedigitallibrary.org/terms-of-use 


\section{Introduction}

The chairs for this SPIE conference on Remote Sensing of Oceans, Sea Ice, and Large Water Regions for the year 2010 wish to thank all of the participants who attended the meetings, the authors who presented oral papers, and especially those who also presented their work in the poster session. The papers accepted for inclusion at the conference and reviewed and accepted for publication represent various stages of new remote sensing science and technology. The chairs are pleased to assist in seeing these papers delivered and available in the open literature-available around the world.

Additionally, we thank the authors from European nations representing the private sector who made outstanding presentations. Several presentations were also made from NASA and EUFAR in airborne remote sensing, and we appreciate their time to attend the meeting and to describe the airborne remote sensing research and activities supported by various organizations.

There are also several papers that described aspects of active and passive remote sensing related to oil detection and monitoring-past, present, and future activities. These were very useful and provided up-to-date information concerning this important topic in the United States at this time.

The session chairs as well as all of the SPIE European and United States staff who worked so hard in advance and after the conference to see the papers through the publication process are to be commended for their excellent efforts as well.

Charles R. Bostater, Jr. Stelios P. Mertikas Xavier Neyt Miguel Velez-Reyes 
Downloaded From: https://www.spiedigitallibrary.org/conference-proceedings-of-spie on 26 Apr 2023

Terms of Use: https://www.spiedigitallibrary.org/terms-of-use 